\title{
Obituary
}

\section{MIRKO DRAŽEN GRMEK}

(1924-2000)

Professor Mirko D Grmek, historian of science and medicine, died in Paris on 6 March 2000 aged seventy-six, at the end of a long and trying disease, amyotrophic lateral sclerosis. "Crossing the borders" can be taken as the motto of his life and work. Without ever losing his cultural and personal roots, he was ready to widen and expand his interests and subjects of work. Of Croatian origin, he became a French citizen, defining himself as a European intellectual. Geographical frontiers, even during the dramatic political crisis and the war in Yugoslavia, during which he ardently defended the cultural and political independence of Croatia, never impeded his work. Cultural and political barriers were nonsense for him. Proudly linked to his own national and cultural roots, but at the same time a true cosmopolitan, he remained open to other cultures and political ideas. He never excluded colleagues and students from his activities because of their origins or political ideas, even in the worse period of the Yugoslav crisis, when sometimes his open attitude was difficult to keep and defend.

As a researcher and teacher, Mirko Grmek crossed several disciplines, becoming in each of them an outstanding scholar and teacher. Trained as a physician, he soon turned to the history of science and medicine, then to philology in one direction and palaeopathology in the other. Nevertheless, he always maintained the highest professional standards, never losing his previous interests and results. There were also no temporal limits for his research, as he studied and published on almost all periods of the history of medicine and biology, from preHippocratic medicine to the history of contemporary medicine and science such as molecular biology and AIDS.

Even his methods were flexible, systematically adapted to the problem he was studying. He was a ardent and sometimes rigid defender of philological correctness and he always preferred primary sources. But at the same time he was able to use critically contemporary knowledge and techniques to "read" anew testimonies from the past. He was able to link the "longue durée", the permanence of themes and ways of thinking thorough the historical epochs, with microchronological analysis, in the French historical tradition of accurate case studies (microhistory). Considering historical events as "biological organisms", in a constant flux, he understood them as functional processes operating within a specific historical milieu. Historical objects are not static, as they are only traces of past events in the present, and therefore they change with our ways of understanding them. "Objective" history is a methodological aim, but it continues to be elusive, the result of incomplete evidence and the inevitable inadequacy of our intellectual tools.

\section{Biographical Profile}

Mirko Dražen Grmek was born in Krapina, Croatia, on 9 January 1924, son of the lawyer Milan and of Vera Santovac. Aged six, he moved with his family to Zagreb. Just before the Second World War he was obliged to spend a long time in a tuberculosis sanatorium. During the war he spent a year at the military academy in Turin, then in 1943, after the fall of Fascism, he joined the resistance and then went to a refugee camp in Switzerland. After a 


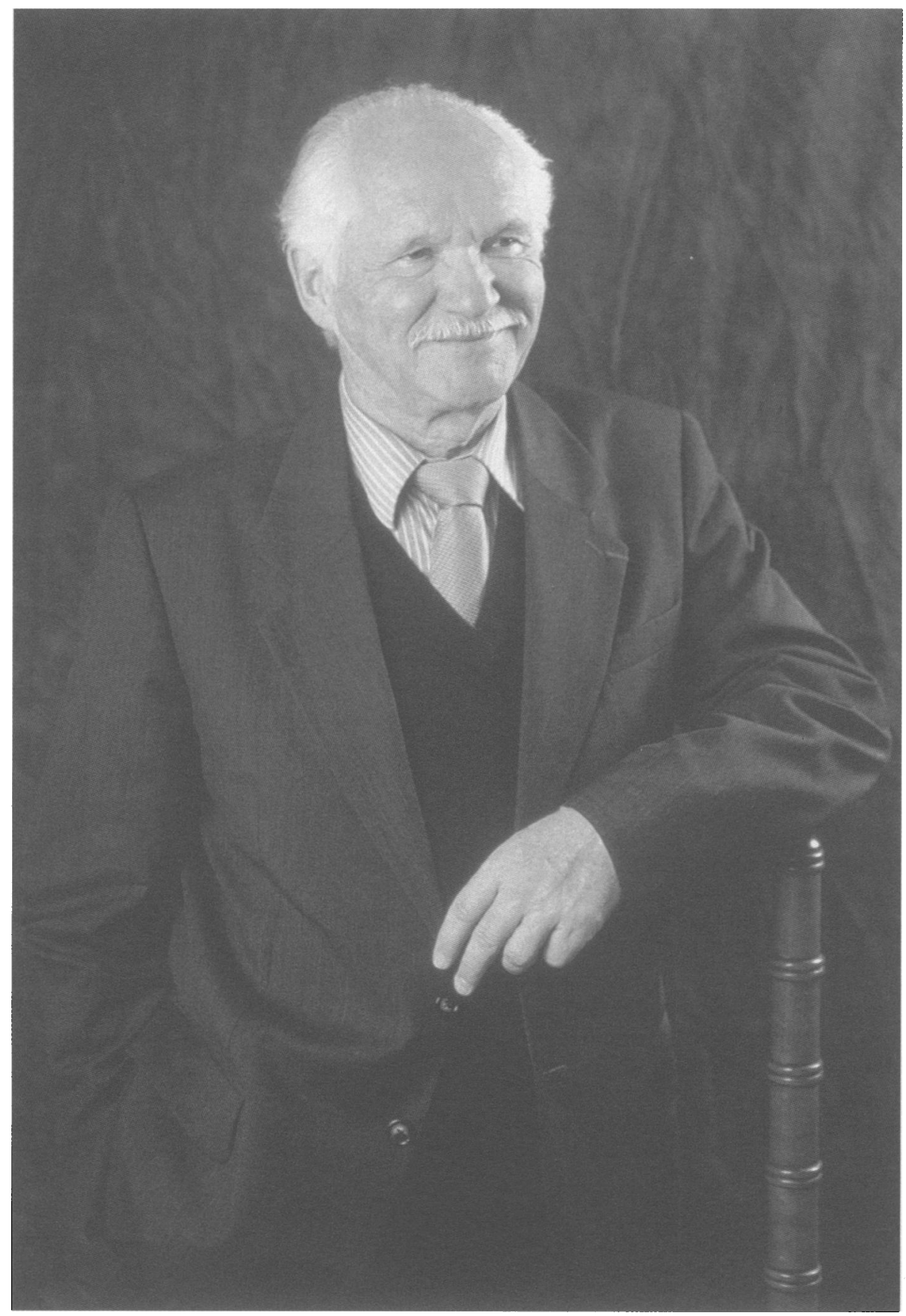

Mirko Dražen Grmek 


\section{Obituary}

period as an intepreter with an American military commission, at the end of the war he returned to Croatia and medical studies. In 1946 he married Sida Valic and his only son, Smiljan, was born in 1953. During his medical training, Grmek began publishing in the history of medicine and his first paper in the field was devoted to Giorgio Baglivi, a historical figure who always remained very present in his researches. His first book was devoted to Santorio Santorio, his "quantitative medicine" and scientific instruments. His early publications were appreciated, especially by the Italian historian of medicine Arturo Castiglioni and by Andrija Stampar, an international authority in the field of public health and the first president of the Commission which created the WHO.

After obtaining his medical degree in 1951, Grmek decided to become a full-time historian of science and medicine, working on the history of medicine in Croatia in the Middle Ages. Stampar and Henry Sigerist helped to create an institute for the history of medicine in Zagreb, with Grmek as its director (1953) and in 1954 he was appointed lecturer at the Zagreb Medical School, charged with an introductory course on medicine. He also was editor-in-chief of the main Croatian medical journal and an associated editor of the Medical Encyclopaedia. At the end of the 1950s, Grmek organized the Museum of the History of Medicine in Zagreb, expanded his researches and participated in several international congresses. The situation in Zagreb proving personally and professionally difficult, Grmek moved to France in 1960, thanks to a fellowship from the CNRS. There he married in 1963 his second wife, the biologist Danièle Guinot.

He devoted the 1960s primarily to cataloguing and to studing the Claude Bernard manuscripts preserved at the Collège de France. This French scientist, the founder of experimental medicine, was the topic of his doctoral degree (1971). In 1967 he became a French citizen, but this period was difficult, as he had to produce a long, major work to be recognized as a member of the French intellectual community. In 1971 he was named "Chargé de conférence" in the teaching directed by Pierre Huard, and two years later he was appointed "Directeur d'étude" at the École Pratique des Hautes Études, Paris, the position he occupied till his retirement in 1989. Grmek cherished this form of advanced teaching in this prestigious institution, which left him complete freedom in the choice of subject and the possibility to combine daily research and advanced courses. His teaching at the EPHE rapidly became a forum for international and interdisciplinary exchanges. Many of his students became professors in France, Croatia, Italy, Switzerland, United States, Canada, and Mexico. He refused offers from prestigious institutions, with administrative duties, and the power connected with them, preferring to remain a researcher and a teacher. After the Seminars at the EPHE the discussion often continued in his small flat in the Quartier Latin, a "meeting point" for many students and colleagues, and a "reference point" for every historian of biology and medicine spending time in Paris.

Always very interested in international collaboration, Grmek became first Secretary (197181) and then President (1981-5) of the Académie International d'Histoire des Sciences, and the editor-in-chief of the journal of the Academy, the Archives Internationals d'Histoire des Sciences. In 1979 he created, in collaboration with Bernardino Fantini, another international journal, History and Philosophy of the Life Sciences, thanks to the support of the Stazione Zoologica di Napoli. The first issue of the journal contains a paper by Grmek which elucidated its principal interest, the relation between history of science and philosophy of science.

Grmek's editorial activity was very intense in the 1980 s and 1990s. He was a director of monograph series (Payot, Fayard), he participated in several scientific committees for encyclopædias and dictionaries of the history of science and medicine, and he edited the first history of Western medical thought (Storia del pensiero medico occidentale), published in Italian and French. Those years were also full of honours and recognition of Grmek's 


\section{Obituary}

contributions to the history of science and medicine. In 1987 Lausanne University awarded him a doctoral degree in philology honoris causa and in 1998 he received another doctoral degree honoris causa in history and philosophy of science from the University of Bologna, in a solemn ceremony on the occasion of the 800th anniversary of this University. In 1991 the History of Science Society awarded Grmek the Sarton Medal, a prestigious honour, which he appreciated deeply.

The years after his retirement in 1989 were full of research and publications, but also very difficult because of his cultural and political participation in the suffering of his country of origin, Croatia, during the crisis of the former Yugoslavia. In 1999 his fatal disease was diagnosed and in the same year his life was touched by another drama, the sudden death at the age forty-six of his only son, Smiljan. Conscious of the approaching end, he spent the last months of his life, with the assistance his third wife, Louise Lambrichs, in publishing his last works and in organizing his library and rich archives, which had been deposited at the French archival centre IMEC. Consistent with his ethics, opposed to therapeutic excesses, he refused to be hospitalized and committed to a life support system, and after his last farewell to his friends, he died on 6 March 2000 , looked after by his wife.

\section{Research Activity and Publications}

Grmek's scientific production covers a wide spectrum of historical periods, problems and methods. An extensive bibliography is listed in the book edited in his honour by Danielle Gourevitch Maladie et maladies, histoire et conceptualisation (Geneva, Droz, 1992) and in the introduction to the critical edition of Aretaeus of Cappadocia (Geneva, Droz, 2000). His complete bibliography is being added to the French translation of his small book La vita, la malattia e la storia (Paris, Le Seuil, 2001). More than one thousand titles are listed there and can be grouped around five main headings.

\section{History of the Experimental Method}

The first group of publications is in the history of biology and biological experimentation from Classical Antiquity (Le chaudron de Médée. L'expérimentation sur le vivant dans l' Antiquité, Paris, Synthélabo,1997) to contemporary molecular biology. The main focus in this field was Claude Bernard, whom Grmek studied at length, producing a subtle scientific and human portrait of the French physiologist and discussing in detail his "logic of scientific discovery", his philosophy and psychology. Studying in depth Bernard's laboratory notebooks, Grmek reconstructed the winding path to a scientific discovery, what he called with a beautiful expression, the "vécu de la decouverte". This was the subject of his doctoral dissertation in Paris (Raisonnement expérimental et recherches toxicologiques chez Claude Bernard, Geneva, Droz, 1973), and he returned to it often (Claude Bernard et la méthode expérimentale, Paris, Payot, 1991; Le legs de Claude Bernard, Paris, Fayard, 1997).

\section{History of Diseases and Disease Concepts}

The second longstanding centre of interest of Mirko Grmek was the history of diseases and the evolution of the concept of disease. More than that, he openly stressed the point that disease is a concept, a theoretical construction, which reflects the ideas but also the pathological reality of a given historical period. This methodological and theoretical point is well developed in his fundamental contribution on Les maladies à l'aube de la civilisation occidentale. 


\section{Obituary}

Recherches sur la réalité pathologique dans le monde grec préhistorique, archaïque et classique (Paris, Payot, Centre National des Lettres, 1983), translated into English as Diseases in the ancient Greek world (Baltimore, Johns Hopkins University Press, 1989). This book is devoted to the reality of diseases at the origins of Western civilization, explored with the most advanced palaeopathological and philological tools. However, this reality is constantly read through a theoretical framework which reveals the links between the reality and the "third world", the world of ideas and concepts. Grmek's discussion of the historical evolution of the concept of disease, in particular in the chapters devoted to this topic in the three volumes of the Storia del pensiero medico occidentale are a major contribution to this subject, which is increasingly fascinating historians, philosophers and sociologists.

In order to understand the complex dynamic of diseases in a given historical situation, in 1969 Grmek coined the neologism pathocoenosis (that is a "community of diseases"), modelled on the biological phenomenon of biocoenosis: in a given population many diseases exist in a complex and dynamic equilibrium, with a few very common diseases and a high number of rare diseases. The pathocoenosis of a population, in a given historical period, can be described by the dominance of a limited number of diseases, as tuberculosis and cholera in Europe in the nineteenth century, cancer and other degenerative disorders in the second half of the twentieth century. Grmek was very proud of the introduction of this term, which is today used without giving reference to its inventor and to the original publication, as it has become part of the standard medical vocabulary.

For the reconstruction of the pathological reality or pathocoenosis in the Mediterranean area in Classical Antiquity, Grmek used a vast array of different tools: medical and literary sources (the number of references in the book is overwhelming), archaeological pieces, retrospective diagnoses based on palaeopathological evidence and also on a detailed analysis of the artistic representations of diseases and pathological states. This last aspect was the subject of the book that Grmek published in 1998, in collaboration with Danielle Gourevitch, Les maladies dans l'art antique (Paris, Fayard), the result of collecting during his travels an incredibly vast amount of photographs and reproductions from hundreds of big and small museums. The careful analyses of the representations of diseases in art, intended or not, what the authors call "iconodiagnostics", produced another source of information relevant for the understanding of the pathological reality of the past.

In the field of the history of disease, Grmek's masterpiece is the History of AIDS (first French edition, Payot, 1989, English edition, Princeton University Press, 1990). Applying rigorous historical methods to the study of a contemporary pandemic, Grmek produced a model of "contemporary history". Using the same method of analyses of laboratory notebooks, published papers and other testimonies, that he had applied with success to his work on Claude Bernard, combining it with oral history and the careful "follow up" of the events in the press and media, Grmek achieved an instructive rational reconstruction of the major event that changed the late-twentieth-century image of medicine. He carefully described the scientific and clinical discoveries, the priority dispute between the French and American teams, the social constructions implied by the debates and finally the historical epidemiology of the disease and the biological, social and cultural causes of its spread.

\section{Scientific Revolutions in Life Sciences}

In his work on the history of the life sciences, Grmek focused mainly on the major discontinuities, and on the personalities and scientific communities that had made them possible. He identified four main discontinuities, and he devoted to each of them a book, articles or biographies. The first discontinuity is the origin of the Western medical tradition 


\section{Obituary}

(Hippocrates and Galen). The second happened in the seventeenth century, the result of an intellectual endeavour that Grmek has named the "first scientific revolution in biology". In this context he studied extensively the contributions by Santorio, Baglivi, R J Boscovich, and Leonardo da Vinci. The third discontinuity coincides with the development of scientific medicine in the nineteenth century, with the origins of clinics (R T H Laënnec) and of laboratory medicine (Claude Bernard). Together with Bernard, Laënnec was a constant of Grmek's historical and epistemological reflections, as he considered him almost as a model for himself, because he combined erudition and classical philology with medical practice and scientific work.

Finally, the fourth discontinuity was produced by molecular biology and the new model of scientific explanation in biology and medicine based on the concepts of information, genetic programmes and genetic regulation. Many papers, including the last one published in French in the Revue Médical de la Suisse Romande, which he considered as his intellectual testament, are devoted to this "contemporary revolution".

\section{Classical Philology}

In this field Grmek's collaboration with other French scholars produced a rich array of beautiful works, which combine classic philosophy with the history of medicine and diseases. In collaboration with Fernand Robert and more recently with Jacques Jouanna he edited several Hippocratic treatises, in particular Epidemics V-VII. In a close collaboration with Danielle Gourevitch, his successor to the chair at the EPHE, who was associated with him from 1968 to the very end of his life, Grmek produced a large number of papers and critical editions of classic medical texts, such as the edition and commentary of the translation by Laënnec of the treatise by Aretaeus of Cappadocia 'On the cause and signs of disease'.

\section{Medical Epistemology and Ethics}

Grmek devoted many papers and a large part of his teaching to epistemological questions, primarily the historical and philosophical accounts of discovery. Through a careful comparison of manuscripts and printed sources, Grmek argued that accounts of discovery are necessarily constructed a posteriori, often the result of historiographic "myths" that frame and direct retrospective stories. In a paper bearing the title 'A plea for freeing the history of scientific discoveries from myth' (in M D Grmek, R S Cohen, G Cimino (eds), On scientific discovery: The Erice Lectures, Dordrecht, D Reidel, 1981), Grmek argued that the roles of imagination and creativity in scientific discoveries are not taken into account in the rational and logical reconstruction of the "vécu de la découverte" and are discarded as "irrational", hence irrelevant. On the contrary, chance plays an important role in science, and scientists often "go to the wild". The creative phases of a discovery or the elaboration of a new theory are not completely explained by a logical analysis. For that reason epistemology cannot be separated from history and the deeply rooted relation between history and philosophy of science and medicine is the only way to understand the growth of knowledge. Myths themselves, argued Grmek in a profound analysis of Pasteur's discovery of the rabies vaccine, are often necessary in science, as they allow a social acceptance and diffusion of a revolutionary science or therapeutic tool.

The very first paper of the newly founded History and Philosophy of the Life Sciences was a sort of "manifesto" of Grmek's epistemological and methodological attitudes. History as a reflection on the past, philosophy as an understanding of present concerns and problems are the two indivisible sides of the same endeavour, the effort to understand the human quest for 


\section{Obituary}

knowledge, to comprehend and accept life, disease and death. In this understanding, ethics plays a relevant role and Grmek, as an humanist and a physician proud of his knowledge, was involved in ethical debates. In his view, bioethics, the reflection on what biology and medicine can or should do, must be grounded in history and epistemology, that is in the study of the origins of what we know and what we do in biological and medical practice. In this context, Grmek contributed a history of the definitions of death, and a discussion of the role of animal and human experimentation. Finally, dramatically confronted with his own experience, in one of his last books (La vita, la malattia e la storia, Rome, Di Rienzo, 1998) he developed an autobiographical discourse, looking at himself as a man of our times who reflects on his own life and is confronted with physical and moral suffering and the consciousness of his own end.

\section{Conclusion}

For everyone who had the chance to meet him and to be his student or colleague, Mirko Grmek will remain a vitae ac studiorum magister, a master and a model of life and studies, not only because of his immense erudition and knowledge, his extraordinary capacity for work, the scope and solidity of his research, the quality of his results, the depth of his constructive criticism, the openness that he always showed to everyone who needed his help and his advice. But also, and perhaps principally, for his reliance on the possibility of understanding nature and history and for his tireless fight for freedom and truth.

Bernardino Fantini,

Institut Louis Jeantet

d'Histoire de la Médecine, Geneva 